\title{
Ritual burning and slaughtering in an AIC: perspectives from Liturgical Studies and Old Testament Criticism
}

\author{
Cas Wepener \& Esias E. Meyer \\ Departments of Practical Theology and Old Testament Studies \\ Faculty of Theology, University of Pretoria
}

\section{Introduction and background}

Multi- and inter-disciplinarity have characterised Liturgical Studies over the past decades, ${ }^{1}$ especially collaboration with the fields of Social and Cultural Anthropology and the domain of Ritual Studies. Furthermore, Liturgical Studies has benefited greatly from field work as a standard part of the methodology in liturgical research, specifically participatory observation; the starting point has thus been the enacted rite as point of departure, while concepts such as (liturgical) inculturation have been an integral part of the on-going discourse in Liturgical Studies. ${ }^{2}$ This chapter offers an example of liturgical research in which two theological fields cooperate in order to investigate one specific repertoire of liturgical rituals. Apart from Liturgical Studies, the article also features a contribution from Old Testament studies on how biblical critics understand certain rituals described in the Priestly texts in the Pentateuch. Ritual Studies is beginning to play a much more prominent role in the engagement with books such as Leviticus and Numbers. ${ }^{3}$ As such, this article is part of a larger research project.

Between 2008 and 2011 an international and inter-disciplinary team of researchers has been working together in an NRF-funded research project under the title "Exploring the role of religious rituals for social capital formation". ${ }^{4}$ In this article we will indirectly address the

${ }^{1}$ Cf. Paul Post, "Zeven notities over rituele verandering, traditie en (vergelijkende) liturgiewetenschap," Jaarboek voor liturgie-onderzoek 11 (1995): 1-30.

${ }^{2}$ For a discussion on themes and trends in Liturgical Studies in the period 1995-2005 cf. Paul Post, Liturgische bewegingen. Thema's, trends en perspectieven in tien jaar liturgiestudie. Een literatuurverkenning 1995-2005 (Zoetermeer: Uitgeverij Meinema, 2006). For a specific discussion on the use of participatory observation in liturgical research, see Clare Johnson, "Researching Ritual Practice," Studia Liturgica 35/2 (2005): 204-220; Martin Stringer, On the perception of worship, (Birmingham: Birmingham University Press, 1999), as well as Cas Wepener, "Researching Rituals. On the use of participatory action research in liturgical studies," Practical Theology in South Africa 20/1 (2005): 109-127. With regards to the methods of data collection as well as the presentation of data pertaining to worship in Missiology, which closely correspond to the way in which liturgists will go about documenting the phenomenon, cf. Sundkler's "Introduction" as well as description of AIC worship in his by now classic Bantu Prophets in South Africa. Second Edition (London/ New York/ Toronto: Oxford University Press, 1961), and also for a much more recent text Dana Robert \& Martinus Daneel, "Worship among Apostles and Zionists in Southern Africa," in Christian Worship Worldwide. Expanding Horizons, Deepening Practices, (ed. Charles Farhadian, The Calvin Institute of Christian Worship Liturgical Studies Series, Grand Rapids: W.B. Eerdmans, 2007), 43-70; with regard to the concept of inculturation, cf. David Bosch, 1991. Transforming Mission. Paradigm Shifts in Theology of Mission (Maryknoll, NY: Orbis Books).

${ }^{3}$ See, for instance, the following three examples of studies on Leviticus: Wesley J. Bergen, Reading Ritual. Leviticus in Postmodern Culture (London: T \& T Clark, 2005); Bryan D. Bibb, Ritual Words and Narrative Worlds in the Book of Leviticus (London: T \& T Clark, 2009); Leigh M. Trevaskis, Holiness, Ethics, and Ritual in Leviticus (Sheffield: Sheffield Phoenix Press, 2011.

${ }^{4}$ This material is based on work supported by the South African National Research Foundation (NRF) under Grant number 73974. Any opinion, findings and conclusions or recommendations expressed in this material are those of the authors and therefore the NRF does not accept any liability in regard thereto. For a general outline of the project cf. Cas Wepener; Ignatius Swart; Gerrie ter Haar \& Marcel Barnard, "The role of religious ritual in social capital formation. Theoretical and methodological points of departure of a South African exploration in progress," Religion \& Theology 17, No. 1\&2 (2010): 61-82; and for a description of the process of how this 
central question of this project by focusing on one AIC denomination and specifically also one AIC congregation participating in this project, in particular their use of blood and sacrifice in liturgical rituals, namely the Corinthian Church in South Africa (CCSA) and their congregation in Phepheni (Eastern Cape) and one annual service in Mlazi (KwaZulu-Natal). In short it can be stated that this repertoire of liturgical rituals is performed with the aim of cleansing and the main aim of cleansing in this denomination is inclusion. This basic but central finding is an important perspective on the role of religious rituals in social capital formation. Moreover, to be able to come to such a conclusion it was necessary to re-visit one concept and one method, namely liturgical inculturation as used in modern Ritual Liturgical Studies, and the way that Hebrew Bible scholars interpret the texts on which some of these rituals are apparently based.

The data and the method by which these data were collected will be described first. Then the notion of liturgical inculturation will be briefly presented, which will also incorporate recent developments of the concept in Liturgical Studies. This discussion of liturgical inculturation will be followed by an argument for a re-appreciation of Priestly texts $(P)$ in the light of recent Old Testament scholarship as well as the data gathered. In conclusion, the authors will elaborate on the perspective these insights offer when the notion of liturgical inculturation and the re-appreciation of $\mathrm{P}$ are applied to the collected data.

\section{Research methodology and description of the collected data}

In the Northern mountainous region of the Eastern Cape Province is the rural village of Phepheni. Most of the inhabitants are Xhosas making a living of subsistence farming; nevertheless, in general the people of the village can be described as being financially very poor, with an unemployment rate, according to Statistics South Africa, of over $90 \%{ }^{5}$ The village also has no electricity or running water. In the village there is a congregation of the CCSA that was founded about 1952 by the late Bishop Johannes Richmond, then from Mlazi outside Durban in KwaZulu-Natal. ${ }^{6}$ This denomination has a rich and varied worship life, but in this chapter we will concentrate only on the use of blood and sacrifice in their worship.

The data were collected by means of participatory observation of various Sunday worship services between 2008 and 2011 in Phepheni and one of the authors also attended the allnight Isitshisa service in Mlazi in 2010 commencing on the evening of the last Saturday in October. Along with these descriptions of the actually performed worship services, various individual interviews were conducted with, amongst others, the widow of the late founder of the church on 27 June 2011 in Weybank, KwaZulu-Natal; a focus group interview focussing specifically on the theme of blood and sacrifice was also conducted on 25 April 2011 in Phepheni during which a representative group of the local congregation was present. During this focus group the main priest of the congregation in Phepheni, Rev. P.W. Dingaan, remarked that there are three things that distinguish the CCSA from other similar churches:

particular research field was entered see Cas Wepener \& Marcel Barnard, "Entering the field. Initiating Liturgical Research in an AIC," Acta Theologica 30/2 (2010): 192-210.

${ }^{5}$ The data on employment are unfortunately not complete. However, of the 232 inhabitants of Phepheni, 46 persons indicated that they cannot find work, with a further 12 being unemployed or choosing not to work, and quite a number being in school or home-makers/housewives, and a further 118 indicating that 'occupation' on the census forms is not applicable to them; the situation regarding employment therefore does appear to be bleak. All the statistics are based on statistics acquired from Statistics South Africa and based on figures from the 2001 census. Specific reports used here include Geography by "population group", "language", "employment status" and "income".

${ }^{6}$ Information regarding the history of the Corinthian Church of South Africa and its founder was obtained from an interview with the widow of the founder and one of his daughters on 27 June 2011 in Weybank, Durban. 
they always stand during worship, they never eat at funerals and they perform sacrifices. We are not convinced that they are the only AIC denomination with these unique characteristics; however, there is a possibility that these aspects are indeed fairly unique, especially the sacrifices. ${ }^{7}$ When we refer in this chapter to sacrifice, we are describing a ritual that entails the killing and burning of an animal on an altar at a church or on the ground in the mountain. Such a sacrifice is not for consumption, but the animal is burnt completely ${ }^{8}$. But for a fuller picture, the use of blood in general in liturgical rituals must also be investigated.

\subsection{The annual Isitshisa in Mlazi}

Every year on the last Saturday of October members of the CCSA from various provinces gather at the church in Mlazi where the founder of the denomination, Johannes Richmond, was the priest and where, according to respondents, he received his visions. From Saturday afternoon onwards buses and minibuses start to arrive with the members and continue to do so until late in the evening. In the early evening the worship service commences in the church building. The various liturgical rituals that take place on such occasions and that are performed by thousands of participants are impossible to describe in the space of one article; we therefore only highlight the liturgical rituals that include the use of blood and sacrifice. $^{9}$

- Around midnight a goat is lead into the church and all those who will be ordained in special offices in the church (deacons, priests, evangelists, bishops) are seated on chairs in the front of the church. Only one goat is brought into the church, although every initiate should have brought his/her goat (if they can afford one) and the bishops and priests pray over both the goat and the initiates. This goat is later slaughtered and all the goat's blood is poured into one container. The blood is then mixed with water and smeared over the faces and hands of those being ordained. The goat is finally sacrificed, not for consumption but completely burnt. This is not the main sacrifice at this worship service, but part of the service specifically focusing on ordination.

- Whilst all the activities are occurring in the building, all the time roughly a third of the participants are outside doing various other things such as talking to people they last saw a year ago at Isitshisa, men slaughtering sheep at the back of the church to be cooked and eaten, while others in front of the church build an altar of large stones on top of which big pieces of firewood are placed. This altar and fire wood are for the sacrifice of the heifer that occurs much later and towards the end of the service.

\footnotetext{
${ }^{7}$ For a discussion of commensality in this congregation and community, see Cas Wepener, "Snert. Ritualliturgical measurements and recipes for social capital," Verbum \& Ecclesia 31 (2010): 1-7.

${ }^{8}$ Sundkler refers several times to sacrifice, but then always just in relation to the killing of an animal and he does not describe or mention the burning of the animal on an altar as the Corinthians practice it. Cf. Sundkler, Bantu Prophets, 250-1, 260. Mfusi's discussion of sacrifice also seems to refer to slaughtering; see S. Mfusi, "Religious Communication: Prayer, Sacrifice and Divination," in: Kitshoff, M.C. "African Independent Churches Today: Kaleidoscope of African Christianity", African Studies Volume 44, (ed. M. Kitshoff: Lewiston/ Queenston/Lampeter: The Edwin Mellen Press, 1996), 193-196. In Thomas Oduro et al., Mission in an African Way. A practical introduction to African Instituted Churches and their sense of mission, (Wellington: CLF \& Biblemedia, 2008), 83-84, sacrifices in AICs are indeed dealt with and, according to the authors, are mostly found in traditional and not in reforming AICs.

${ }^{9}$ For similar descriptions of Isitshisa cf. Henry Mbaya, "The socio-practical dimensions of isitshisa [burning of the heifer] in the Corinthian Church of South Africa", HTS Teologiese Studies/ Theological Studies 67, No.2 (2011): Art. \#930, 8 pages. doi:10.4102/hts.v67i2.930.
} 
- During the early hours of the morning, after all members of the congregation have arrived, the heifer is burnt on the altar. This sacrifice is not for consumption by anyone, seeing that the whole animal is sacrificed and only its blood and the ashes are kept for use in other liturgical rituals, such as cleansing rituals after attending a funeral and many others, similar to the occasions described in 2.3 below.

- In the last stage of this worship service a bus full of poor blind people is brought to church every year, as instructed by the founder. Food that was collected during the service as well as some of the money is then donated to them and they share the meal of mutton that has been prepared from the sheep slaughtered outside the church building during the service.

According to Rev. Dingaan, the sacrifice of the heifer in Mlazi is conducted in accordance with Numbers 19.

\subsection{Sacrificing in Phepheni}

Sometimes, if they have received a vision in Mlazi during the Isitshisa service to do so, the congregation in Phepheni will, once they arrive back home, go to a specific mountain nearby and sacrifice an animal in a similar way there. They will not sacrifice a heifer, but usually a sheep or even a chicken. Once again the whole animal is burnt. According to the widow of the founder, this is done in most congregations when the bishop of the area decides that it is needed and the ashes are kept for ritual purposes. ${ }^{10}$

\subsection{Other occasions and rituals that include slaughtering and blood}

During the focus group discussion on sacrifice, slaughtering and blood it became apparent that there is a whole repertoire of liturgical rituals which requires slaughtering and/or blood, apart from the two sacrifices mentioned above. Responding to the question to list all the instances in which blood is ritually used in their church, the respondents mentioned the following:

- To cleanse someone who is mourning. After the mourning time is over (for a husband who died, after 12 months; for a wife, after 6 months; a child, after 3 months; a still-born baby, after 1 month; and a husband who died in an accident, after 6 months), they slaughter an animal. The family will decide whether it will be a sheep, a goat, a cow or a chicken, depending on their specific culture and also on their financial position;

- Welcoming a new-born child after between 1 and 3 months, but not after more than 5 months. Here, as in the following three examples, the animal(s) is slaughtered and the meat cooked and consumed;

- Welcoming a new wife in a ceremony they call indlakudla;

- At a wedding;

- For reconciliation;

- After the initiation of boys and girls;

- After a funeral 'to drink water' and 'the washing of the pick axes'; the latter involves a meal shared by the immediate family of the deceased some time after the funeral; ${ }^{11}$

\footnotetext{
${ }^{10}$ Interview with Mrs Richmond, 27 June 2011.

${ }^{11}$ For a description of these rituals as documented for a previous research project, cf. Cas Wepener, Van vas tot fees. 'n Ritueel-liturgiese ondersoek na versoening binne Suid-Afrikaanse kultuurkontekste, (DTh, University of Stellenbosch, 2004), 527.
} 
- When someone is sick, they say the ancestors are complaining and we have to slaughter,

- After a funeral, everyone who attended must wash their hands with a mix of water and the intestines of a chicken or sheep or goat that was slaughtered;

- When an isangoma comes back to the church, blood is used. He/she cannot come into church, but must wait outside with their chicken or goat to be purified and then the priest appoints someone to go out and slaughter and mix the intestines with water and pray over it. They then put the mixture into two buckets (a 20-litre bucket and a 5-litre bucket). The 20 litres of mixture is poured over the isangoma and the 5 litres sprinkled in the church;

- A mother must stay at home after a birth - 66 days for a daughter and 33 days for a boy. After this period she takes a chicken and waits outside the church building with the chicken. A member is then sent out to slaughter the chicken, mix the intestines and water, and sprinkle the mother and the baby with it. This is done, according to the respondents, in accordance with Leviticus 12.

- Sometimes when members from Phepheni in the Eastern Cape cannot go to Mlazi, a sheep or goat is slaughtered. The blood is put in a basin and Rev. Dingaan takes a ladder and goes to the church. He puts his right hand in the blood and then puts this hand covered in blood over the door post and also over the window frames of the church to make an impression of blood there. This, according to respondents, is according to Exodus and what the Israelites did when they fled Egypt.

It can finally also be noted that in all of the above instances only an ordained priest is allowed to touch the blood to be used in liturgical rituals.

\subsection{The symbolism of blood and sacrifice}

During the interviews and the focus group in Phepheni respondents were asked about the meaning of blood and sacrifice to them. Their answers are multilayered and complex to interpret, and derive from a mixture of symbolism and texts from both the Old and New Testaments, as well as traditional Xhosa culture. We will here provide a summarised description of their responses.

- A central symbol is the blood and water flowing from Jesus' side, but the references to blood in texts related to the Eucharist in the Bible are also a key.

- $\quad$ Two texts from the Old Testament were continually quoted as legitimisation for the ritual use of sacrifice and blood as well as the timing of the rituals, namely Leviticus 12 and Numbers 19. In this regard one priest remarked: "See, we take the examples from the Bible and do it exactly like that. This is on purpose, so when anyone asks us why we do something like this, we can answer them".

- A connection was also made between their sacrificing in the mountain in Phepheni and Genesis 22 (Abraham and Isaac).

- The respondents also connected the use of blood and sacrifice to traditional Xhosa culture such as initiation, the ancestors and even isangoma.

- Most importantly, however, it seems that the main purpose of liturgical rituals in which blood is used is cleansing. And cleansing they explain as follows: "To be cleaned as a person is different to being sick like a stroke or a fit; it is rather like after birth and for a special time like you read about in the Bible. If you have to be cleansed, it is always because of a specific reason such as death or birth. Cleansing means you were 'out' of the church and 
this 'welcomes you back' again. See, a church is totally different from the community; it is holy, people who cannot enter are like drunk people, isangoma, people who just do not like church."

\section{Liturgical inculturation}

By now it will be evident that there is a dynamic interaction in the CCSA between their worship/liturgy/cult and the surrounding culture, as is the case in all churches' liturgies. This dynamic interaction between liturgy or worship and the culture within which a new form of worship comes into being is often referred to in the literature on the subject as liturgical inculturation. This section will present a brief overview of the development of the concept of inculturation as described by, amongst others, David Bosch, as well as a description of recent avatars of this notion in Liturgical Studies.

The process in which Western theology was basically just transplanted, with a few superficial adaptations, into other cultures is known as adaptation. ${ }^{12}$ Along with adaptation, another important predecessor of inculturation was acculturation, which refers to contact between two groups from different cultures on a lasting and direct level, which leads to a change in the cultural patterns of both groups. ${ }^{13}$ This exchange of cultural elements, however, remains selective and in fact, according to Frijhoff, ${ }^{14}$ complete integration, called assimilation, exists only in theory and not in practice. According to Lukken, ${ }^{15}$ acculturation is about a kind of translation of the Gospel (and liturgy) with the realisation that a word-for-word or literal translation is inadequate. Several forces worked against processes such as adaptation and acculturation. According to Bosch, ${ }^{16}$ these include the rise of nationalism in the Third World; the rise of anthropological thinking, which showed how contextually bound all cultures are; the maturing of the younger churches (amongst others). All of these developments made the necessity for a new system apparent. One response to this growing need was inculturation.

When examined on a morphological level, it is immediately apparent that something is being added 'into' culture in the process of inculturation. Basically the concept of liturgical inculturation entails a critical-reciprocal interaction or enrichment between cult/liturgy and culture in such a way that a whole new entity comes into being, namely an inculturated liturgy. Lukken calls liturgical inculturation a continuous process of critical interaction and assimilation between both culture and liturgy or the Christian message. ${ }^{17}$ And according to

\footnotetext{
12 For an overview of the development of the concept of inculturation in relation to mission, cf. Bosch, Transforming Mission, 447-457; and specifically applied to liturgy, cf. Cas Wepener, From fast to feast. A ritualliturgical exploration of reconciliation in South African cultural contexts, Liturgia Condenda 19 (Leuven: Peeters Pers, 2009), 36-42.

${ }^{13}$ See Willem Frijhoff, “Toeëigening: van bezitsdrang naar betekenisgeving”. Trajecta 6 No. 2 (1997): 105-106.

${ }^{14}$ Frijhoff, "Toeëigening", 106.

${ }^{15}$ See Gerard Lukken, Inculturatie en de toekoms van de liturgie, (Heeswijk-Dinther: Uitgeverij Abdij van Berne, 1994), 9; Gerard Lukken, "Inculturatie van de liturgie: theorie en praktijk," Liturgie en inculturatie, (ed. Josef Lamberts, Leuven: Uitgeverij Acco, 1996).

${ }^{16}$ See Bosch, Transforming Mission, 450.

${ }^{17}$ See Lukken, "Inculturatie van de liturgie", 22. For the concept of liturgical inculturation see also, amongst many others, D. Amalorpavadass, "Theological Reflections on Inculturation," Studia Liturgica 20 (1990) 36-54; Anscar Chupungco, "Inculturation of Worship: Forty Years of Progress and Tradition," Liturgical Institute Conference Proceedings. Paper 5 (2003) http://scholar.valpo.edu/ils_papers/5; Anscar Chupungco, "Mission and Inculturation: East Asia and the Pacific," in The Oxford History of Christian Worship, (eds. Geoffrey Wainwright \& Karen Westerfield-Tucker: Oxford: Oxford University Press, 2006), 661-677; Nwaka Egbulum, "Mission and Inculturation: Africa," (eds. Geoffrey Wainwright \& Karen Westerfield-Tucker: Oxford: Oxford University Press, 2006), 678-695; Lutheran World Federation, "Chicago Statement on Worship and Culture: Baptism and Rites of Life Passage," (1998); Ben de Klerk, "Wisselwerking tussen liturgie en kultuur in die Suid-
} 
Van Tongeren, it is exactly this so-called reciprocal integration which distinguishes inculturation from other concepts such as enculturation, indigenisation, adaptation and accommodation. ${ }^{18}$ Chupungco ${ }^{19}$ describes the process of liturgical inculturation in terms of a mathematical comparison, namely that $A$ (liturgy) $+B$ (culture) $=C$ (a new entity/inculturated liturgy) and not $A+B=A B$. In this process of liturgical inculturation the liturgy criticises or rejects some aspects of the culture and embraces others, and vice versa.

In recent publications the concept of liturgical inculturation has been challenged for various reasons. Three suggestions by liturgists in this regard will be presented here, namely liturgical interculturation, re-inventing liturgy and the dynamics of cult and culture.

- Liturgical interculturation: Working with Bosch's notion of interculturation and applying it to liturgy, one suggestion for a more adequate concept has been that of liturgical interculturation. ${ }^{20}$ The arguments supporting a preference for liturgical interculturation above liturgical inculturation is the impression that inculturation is static, namely that the process of inculturation can be completed. According to Bosch, one can never use the term 'inculturated'. ${ }^{21}$ Looked at on a morphological level, the concept can mistakenly seem to imply one-way-traffic in which something is planted into a culture (inculturation), thus negating the reciprocal nature of inculturation as well as promoting an idea of culture as being a phenomenon which exists in the singular. Therefore the concept of liturgical interculturation is preferred to liturgical inculturation.

- Re-inventing liturgy: In his study of literature in Liturgical and Ritual Studies Paul Post entitled a chapter in his book "Liturgiewetenschap in beweging: van liturgische inculturatie tot re-inventing liturgy". ${ }^{22}$ The idea of re-inventing he gets from the Ritual Studies expert Ronald Grimes and especially his 2000 book entitled Deeply into the bone. Re-inventing rites of passage. According to Post, the movement from liturgical inculturation to re-inventing liturgy is a sign that liturgy has moved beyond the Liturgical Movement and into new territory not confined to the parameters of inner ecclesial liturgical celebration, but has become much broader. ${ }^{23}$ Re-inventing liturgy is a concept that can thus also embrace liturgical rituals found in other spaces than traditional ecclesial spaces, such as in the open air or on the internet. ${ }^{24}$

Afrikaanse konteks - Enkele vertrekpunte", Practical Theology in South Africa 16 No. 2 (2001): 57-75; Peter Phan, "Liturgical Inculturation: Unity in Diversity in the Postmodern Age" in Liturgy in a Postmodern World (ed. Keith Pecklers: London/ New York, 2006); Aylward Shorter, Towards a Theology of Inculturation, (Maryknoll, NY: Orbis Books, 1998).

${ }^{18}$ See Louis van Tongeren, “De inculturatie van de liturgie tot (stil)stand gebracht?," Jaarboek voor liturgieonderzoek 12 (1996): 164-186.

${ }^{19}$ Anscar Chupungco, Cultural Adaptation of the Liturgy, (New York: Paulist Press, 1982), 81.

${ }^{20}$ For this notion of liturgical interculturation, cf. Cas Wepener, "Participation and power: Opportunities for method and theory in liturgical research from a changing (Dutch Reformed) South African liturgical landscape". Jaarboek voor liturgie-onderzoek 22 (2006): 49-66, as well as Wepener, From fast to feast 39-41.

${ }^{21}$ Bosch, Trandforming Mission 455.

${ }^{22}$ Cf. Post, Liturgische bewegingen, 11.

${ }^{23}$ Cf. Post, Liturgische bewegingen, 65-66.

${ }^{24}$ For a descriptive exploration in this regard, see Cas Wepener, "Nuwe tendense buite-om die erediens van die 21ste eeu. 'n Beskrywende liturgie-historiese en hedendaagse verkenning," Nederduitse Gereformeerde Teologiese Tydskrif 52 no. 1\&2 (2011): 257-271; as well as, Cas Wepener, "Ontdek eietydse tendense en uitdagings rondom die erediens," in Ontdekkings in die erediens, ( eds. Cas Wepener \& Johan van der Merwe: Wellington: Lux Verbi.BM, 2009), 181-194. 
- The dynamics of cult and culture: Post's Protestant colleague in the Netherlands, Marcel Barnard, ${ }^{25}$ prefers "the dynamics of cult and culture", an expression closely related to Post's re-inventing liturgy and that is also more open to embrace more ritualistic phenomena than what has traditionally been defined as liturgy as well as the reciprocity between both cult and culture in which both cult and culture are changed by each other.

We summarise some important observations from this brief historical survey of the concept of liturgical inculturation and its more recent avatars that need to be added to the traditional understanding of the concept as follows:

- a reciprocity in which all involved in the process are teachable, not just those on the so-called receiving end;

- a departure from a culture-pessimistic stance to also embracing a culture-positive position without negating the counter-cultural dynamic inherent in the process;

- a movement beyond the parameters of exclusively inner ecclesial liturgy to incorporation of a wider range of liturgical rituals;

- a movement beyond an understanding of liturgy having an unchangeable essence and culture as an entity into which this essence is transplanted to the acknowledgment of a dynamic reciprocity between liturgy and culture in which both are continuously formed and reshaped.

We are of the opinion that these developments regarding the concept are also valuable to our study. They enable us to adopt a broader approach to liturgy than just Sunday morning worship and also to study liturgical rituals that have traditionally received little attention from liturgists. Furthermore, they enable us also to temper our very critical disposition traditional in especially Protestant theological circles -towards rituals, including AIC liturgical rituals, and also to search for possible positive qualities in liturgical rituals such as the repertoire pertaining to blood and sacrifice described above. Lastly, without negating the importance of the counter-cultural dynamics in liturgy and worship, the way in which certain rituals can embrace different cultures, church denominations and even religions can now also be appreciated in a more positive light. This last point brings us to a discussion in recent Old Testament scholarship, namely a re-appreciation of $P$ texts dealing with rituals. We may add here that the founder of the CCSA had, according to his wife and one of his daughters, a particular view of the Old Testament. To quote his daughter in this regard: "See, my father believed in the Old Testament, he did not so much believe in the New Testament. He said: 'why must the Old Testament change? Was it not God who inspired it? Will East one day become West or the other way around? No!' Most of what we do comes from the Old Testament, but we do use the New Testament for preaching". ${ }^{26}$ During the same interview, however, the founder's commitment to Jesus Christ and other New Testament theological aspects were also emphasised by the respondents. This comment, we believe, should not so much be understood against a theological doctrinal background, but rather a ritual background, specifically an appreciation of the ritual texture of some Old Testament texts and how they resonate in a special way in certain cultural contexts. This brings us to the Pentateuch and in particular Leviticus, Numbers and P.

\section{A re-appreciation of $P$ and ritualistic texts}

\footnotetext{
${ }^{25}$ See in this regard Marcel Barnard, "African worship in the Amsterdam business district: Liturgy in immigrant churches," in A Moving God. Immigrant Churches in the Netherlands, (eds. Mechteld Jansen \& Hijme Stoffels: Berlin/ Vienna: LIT Verlag, 2008), 115-137.

${ }^{26}$ Interview conducted in Weybank, Durban, 27 June 2011.
} 
Most of the rituals described above are from texts which Pentateuch scholars would call Priestly texts (P). These texts are found in the first four books of the Pentateuch and are especially present in books such as Leviticus and Numbers. We will be engaging with Numbers 19 below, since this text is explicitly connected to the ritual of Isitshisa above.

The term Priestly Code goes back to the Dutch scholar Abraham Kuenen, who first referred to the Priestercodex, ${ }^{27}$ but it was the source theory of Julius Wellhausen, who established the classic order of the Pentateuchal sources as the Elohist (E), the Yahwist (J), Deuteronomy (D) and the Priestly source (P). For Wellhausen $P$ was an independent source consisting of narrative material (especially found in Genesis and the first half of Exodus) and legal material (especially in the second half of Exodus and, of course, Leviticus and Numbers). For Wellhausen $\mathrm{P}$ was the last source added to the Pentateuch and also represented the last stage of the development of the religion of Ancient Israel. In Wellhausen's understanding this development in the religion of Israel was to be dated to the exilic and post-exilic period. More importantly, for Wellhausen the last post-exilic phase of the development of Israelite religion represented deterioration. Israelite religion went downhill from the pre-exilic prophets to the post-exilic priests. An example often referred to ${ }^{28}$ would be Wellhausen's view of the evolution of sacrifices and festivals. In the time of the monarchy these rituals were "dictated by seasonal labour" and families would spontaneously sacrifice at local sanctuaries in response to harvests and other factors determined by nature. This started to change during the Deuteronomic reform under King Josiah, when the cult was centralised and festivals were now tied to events in Israel's past. The liturgical calendar was no longer connected to life and nature. In its final (Priestly) phase this connection was totally severed and we find precise calendars in Priestly texts such as Leviticus 16 and 23 . Collins ${ }^{29}$ makes the point well:

In Wellhausen's view, the Priestly theology reflected the decline of Israelite religion, from the spiritual heights of the prophets to the legalism of 'Late Judaism'.

Many critics of Wellhausen have pointed out that Wellhausen was reading the Pentateuch like a typical anti-ritual Protestant. ${ }^{30}$ The end result of Wellhausen's understanding of $P$ was that for the first half of the $20^{\text {th }}$ century scholars did not engage with Priestly texts and especially books such as Leviticus and Numbers, at least not on the same level as with other books from the Pentateuch such as Genesis, Exodus and Deuteronomy. Priestly texts were regarded as somewhat tainted by the charge of "legalism".

Things only started to change by the second half of the $20^{\text {th }}$ century. In this regard, the contribution made by the anthropologist Mary Douglas has been substantial. ${ }^{31}$ Many Jewish scholars also contributed to a kind of re-evaluation of Priestly texts, of whom Jacob Milgrom and Baruch Levine are good examples. We will be engaging with their work below. Even in

\footnotetext{
${ }^{27}$ Jean-Louis Ska, Introduction to Reading the Pentateuch (Winona Lake: Eisenbrauns, 2006), 109-110.

${ }^{28}$ See Ska, Introduction, 110. See also Joseph Blenkinsopp, The Pentateuch. An Introduction to the first five Books of the Bible (London: Yale University Press, 1992), 9-12.

${ }^{29}$ John J. Collins, Introduction to the Hebrew Bible (Minneapolis: Fortress Press, 2004), 173.

${ }^{30}$ See Ska, Introduction, 111. He argues that Wellhausen was "translating the Lutheran 'creed' regarding the Law and the Gospel into historical categories."

${ }^{31}$ Mary Douglas, Purity and Danger: An Analysis of Concepts of Pollution and Taboo (London: Routledge \& Kegan Paul, 1966). This book did generate new interest in the book of Leviticus. Other more recent contributions include: Mary Douglas, In the Wilderness: the Doctrine of Defilement in the Book of Numbers (Sheffield: JSOT Press, 1993) and Mary Douglas, Leviticus as Literature (Oxford: Oxford University Press, 1999).
} 
the European ${ }^{32}$ and North American ${ }^{33}$ contexts we saw a little explosion ${ }^{34}$ in books on Leviticus and Numbers ${ }^{35}$ towards the end of the $20^{\text {th }}$ century and the beginning of the $21^{\text {st }} .{ }^{36}$ The tide has clearly turned for Priestly texts and scholars are attempting to re-evaluate the theological value of Priestly texts. Thus the late Erich Zenger argued that against earlier "beliebten Negativzensuren wonach die P-Texte ritualistich, steril und epigonal seien, wird heute die Bedeutung von $P$, vor allem der Priestergrundschrift, meist hoch veranschlagt...."37

\subsection{Numbers 19 and the ritual of the red heifer}

If we still follow Wellhausen's original idea that the Priestly text is a rather late post-exilic text, then the question is where Numbers 19 would fit in? Here it seems that the jury is still out, even amongst scholars who date $P$ to the post-exilic era. Some would argue that, although the text has clearly been edited by Priestly redactors, there might be an older ritual behind this text dating to the monarchical period. Thus Dozeman ${ }^{38}$ would identify the "red heifer" ritual as a possible example of a pre-exilic priestly law, but one page later he presents chapters 18 and 19 as part of the "priestly history". ${ }^{39}$ The reason for this "contradiction" is simply that the text as we have it now is so embedded in P that it is rather difficult to identify an earlier layer within it, but the question is whether the origins of this ritual do not lie in pre-exilic Judah. Other scholars ${ }^{40}$ are more adamant that the text is post-exilic and also post-P.

For the sake of this article we will treat Numbers 19 as a Priestly text. Even if this text is probably later than $\mathrm{P}$, it still has much in common with the original Priestly texts in terms of world view ${ }^{41}$ and these texts were, of course, also written by priests. Another important reason is that Numbers 19 has a lot in common with earlier texts from Leviticus which are undisputed $\mathrm{P}$ texts. With regard to the placement of Numbers 19 in the book of Numbers, Jacob Milgrom has said that "by dint of its theme, corpse contamination, one would have expected it to have been placed with the other impurity sources described in Leviticus 11-

\footnotetext{
${ }^{32}$ Good examples from Europe on parts of Leviticus are: Klaus Grünwaldt, Das Heiligkeitzgesetz Leviticus 17-26. Ursprünglische Gestalt, Tradition und Theologie (Berlin: Walter de Gruyter, 1999). Andreas Ruwe, "Heiligkeitzgesetz und Priesterschrift": Literaturgeschichtliche und rechtssystematische Untersuchungen zu Leviticus 17,1-26,2 (Tübingen: Mohr Siebeck, 1999). Christophe Nihan, From Priestly Torah to Pentateuch (Tübingen: Mohr Siebeck, 2007).

${ }^{33}$ E.g. Jeffrey R Stackert, Rewriting the Torah: literary revision in Deuteronomy and the Holiness Legislation (Tübingen: Mohr Siebeck, 2006).

${ }^{34}$ See Michael B. Hundley, Keeping Heaven on Earth (Tübingen: Mohr Siebeck), 3 n. 11, who refers to a "recent renaissance" in the study of $\mathrm{P}$. He also offers a short discussion on the contribution of Milgrom and his students to this renaissance (see Hundley, Keeping Heaven, 4).

${ }^{35}$ E.g. Reinhard Achenbach, Die Vollendung der Tora. Studien zur Redaktionsgeschichte des Numuribuches im Kontext von Hexateuch und Pentateuch (Wiesbaden: Harrassowitz Verlag, 2003).

${ }^{36}$ See especially the contributions in French, German and English in Thomas Römer (ed.) The Books of Leviticus and Numbers (Leuven: Peeters, 2008).

${ }^{37}$ Erich Zenger, Einleitung in das Alte Testament. 7. Auflage (Stuttgart: Kohlhammer, 2008), 175.

38 Thomas B. Dozeman, "The Book of Numbers. Introduction, commentary, and reflections," in The New Interpreter's Bible. Volume II (ed. Leander E. Keck: Nashville: Abingdon Press, 1998), 9.

39 Dozeman, "Numbers", 10.

${ }^{40}$ See Horst Seebass "Das Buch Numeri in der heutigen Pentateuchdiskussion," in The Books of Leviticus and Number (Ed. Thomas Römer; Leuven: Peeters, 2008), 238-239, who argues that Numbers 19:1-22 belongs to the latest redaction of the book, which he dates to the $4^{\text {th }}$ century BCE, which makes it a post-P text. Or see Achenbach, Vollendung, 525-528, who has a similar opinion that it belongs to a fairly late layer (Theokratische Bearbeitung II), which he also dates to the $4^{\text {th }}$ century.

${ }^{41}$ See, Hundley, Keeping Heaven, 2, for a similar approach.
} 
$15^{\prime \prime}{ }^{42} \mathrm{He}$ is specifically referring to the language of clean/unclean that we find in Numbers 19 , but there are other connections with earlier parts of Leviticus, which will be mentioned below.

In our discussion of the ritual of the red heifer as such, we will be focusing on the commentary by Levine ${ }^{43}$ on the book of Numbers. Levine ${ }^{44}$ describes the ritual of the red heifer as a "rite of riddance". Numbers 19 is about the impurity which one will suffer in coming into contact with a human corpse, a grave or even human bones. The chapter is divided into two parts, namely verses 1-13 and 14-22. The first part is mostly about the mixture which must be prepared for the ritual. The second part is about more specific conditions for contact between contaminating persons. The following aspects of the ritual as identified by Levine are relevant for our discussion.

1) The heifer ${ }^{45}$ is probably red to symbolize blood. ${ }^{46}$ This is important because in the priestly worldview blood represents or symbolises life. Yet this blood is turned into ashes, which represent death. Levine describes this kind of magic as "sympathetic", since "death rids the community of death". ${ }^{47}$

2) As mentioned above, Levine ${ }^{48}$ describes this ritual as a "riddance ritual", which "implies the transfer of sinfulness and impurity to the victim, in this case, to the red cow." Some scholars would also add the word "apotropaic", which refers to rituals which "served to eliminate destructive or demonic forces identified as the source of impurity and viewed as an offense to the deity." ${ }^{49}$ In the case of the red heifer ritual, the "impurity of the dead impacted the Sanctuary". 50 This is especially clear from the fact that after the cow was slaughtered (verse 4), the priest had to sprinkle some of the blood "in the direction of the tent of meeting". 51

3) The riddance ritual is not strictly speaking a sacrifice. It is performed outside the sanctuary pretty far from the altar, probably because the rite itself was considered impure. ${ }^{52}$ This is a rather puzzling aspect of the rite for biblical critics, since it is specifically described as a hatțăt $t$ in verse 9 . We find the hatțăt or, sin

\footnotetext{
42 Jacob Milgrom "Numbers, book of," in The Anchor Bible Dictionary. Volume 4 (Ed. David Noel Freedman; New York: Doubleday, 1992), 1147.

${ }^{43}$ Baruch E. Levine, Numbers 1-20. A New Translation with Introduction and Commentary (New Haven: Yale University Press, 1993).

${ }^{44}$ Levine, Numbers 1-20, 457-458.

${ }^{45}$ The heifer is probably no heifer, but rather a cow, but we do not know enough about "animal husbandry in biblical Israel" to be sure. Levine, Numbers 1-20,461. We will continue to refer to a heifer.

${ }^{46}$ Levine, Numbers 1-20, 460. See also Jacob Milgrom, The JPS Torah Commentary. Numbers במדבר (New York: The Jewish Publication Society, 1990), 158 and Ludwig Schmidt, Das 4. Buch Mose Numeri. Kapitel 10,11-36,13 (Göttingen: Vandenhoeck \& Ruprecht), 86.

${ }^{47}$ Levine, Numbers 1-20, 471.

${ }^{48}$ Levine, Numbers 1-20, 461.

${ }^{49}$ Lauren A.S. Monroe, Josiah's Reform and the Dynamics of Defilement. Israelite Rites of Violence and the Making of a Biblical Text (Oxford: Oxford University Press, 2011), 9. She is actually discussing an earlier work of Levine here.

${ }^{50}$ Levine, Numbers 1-20, 462.

${ }^{51}$ Levine, Numbers 1-20, 462.

${ }^{52}$ Levine, Numbers 1-20, 462.
} 
offering, ${ }^{53}$ or purification offering in Leviticus 4 , where it is a sacrifice performed on the altar to rid the sanctuary of the impurities caused by the sin of the Israelites. ${ }^{54} \mathrm{~A}$ hatțāt is also totally burned and nobody eats any part of it. For Levine riddance also figures prominently in these hatțā't offerings. ${ }^{55}$ The ritual of the red heifer has thus this element of riddance in common with the sin offerings of Leviticus 4 and therefore it is described as such, although it is no sacrifice.

4) This enactment of riddance is also "part of the Yom Kippur purifications ordained in Leviticus 16 and the purification of Aaron and his sons at the time of their investiture, rites described in Leviticus 8-10". ${ }^{56}$

5) Another fascinating difference between the ritual in Numbers 19 and normal hatța ${ }^{\prime} t$ sacrifice is the fact that after the priest has sprinkled some of the blood in the direction of the sanctuary, the rest of the cow, blood included, is burned. With a normal hatțăt the rest of the blood will be sprinkled seven times and some will be smeared on the horns of the altar and then the rest will be poured onto the base of the altar (see Leviticus 4:6-7). Levine ${ }^{57}$ states that "nowhere else in Torah ritual do we find the explicit requirement of burning the blood of a ritual victim". Yet this could mean that the ashes are so much more powerful for ritual purposes, because they include the blood and we have already referred above to the power of blood in the priestly world view. ${ }^{58}$

6) The material (cedar wood, hyssop and scarlet cloth) added to the fire in verse 6 are all found in Leviticus 14:4-6 in rites of purification for people who had șâra'at or skin disease. For Levine this means that these ingredients "had a broad role in purification and riddance." ${ }^{59}$ These three ingredients were burned with the cow.

7) The ashes then became a kind of magic ingredient which was kept outside the camp in a pure place (verse 9). It was later mixed with water when needed; for example, a person who has touched a corpse was regarded to be unclean for seven days and he had to purify himself on days three and seven with this mixture of water and ashes (verse 12). ${ }^{60}$ In verse 13 this mixture is called "water of cleansing" (NRSV). A more elaborate but similar ritual is described in verses 14-20, where a clean person is to sprinkle the same mixture of ashes and water unto unclean people by using a hyssop branch.

\footnotetext{
${ }^{53}$ Levine, Numbers 1-20, 464, prefers to translate hațtā't as a sin offering, as would most translations. Milgrom, JPS Torah, translates it as "purification offering".

${ }^{54}$ See Jacob Milgrom, Leviticus 1-16. A Translation with Introduction and Commentary (New York: Doubleday), 253-292.

${ }^{55}$ See Levine, Numbers 1-20, 461. These offerings are "brought in order to expiate major offenses on the part of the entire Israelite community or its chief priest..."

${ }^{56}$ See Levine, Numbers 1-20, 461-462.

${ }^{57}$ See Levine, Numbers 1-20, 462.

${ }^{58}$ Milgrom, JPS Torah, 159, explains this phenomenon as follows:

The blood is the essential ingredient in the ashes of the red cow. It is the blood of a hatta't, a purification offering, which is the ritual detergent par excellence and which will remove the impurity from those contaminated by contact with corpses. Thus all of the blood from the red cow, except for the few drops sprinkled by the priest, is burned in the fire. Indeed, according to the rabbis, after the sevenfold sprinkling, the High Priest wiped his hand on the carcass to assure that not a single drop of blood was wasted.

${ }^{59}$ See Levine, Numbers 1-20, 462.

${ }^{60}$ The Hebrew of verse 12 literally says "purify himself with it" and usually "it" is understood to refer to the ashes produced in verse 9 and mixed with water as we see later in verse 17. See Milgrom, JPS Torah, 160.
} 
Although one of the priests above said that they (the Corinthians) did "exactly like that", it is clear that that is not exactly true. The most important differences and similarities between the ritual in Numbers 19 and those described above by the Corinthians are outlined below.

- Although a text such as Numbers 19 is often referred to above, some of the rituals have more in common with what we find in texts from Leviticus. The midnight ritual where people who are to be ordained and the blood of a goat is mixed with water is reminiscent of the ordination we read about in Leviticus 8. There Moses takes some of the blood of the ram of ordination and puts it on the right ear lobe, right thumb and right big toe of Aaron. He then repeats this ritual with the sons of Aaron (verses 22-25). Then Moses takes some of the anointing oil and mixes it with the blood in the altar and sprinkles the mixture on the garments of Aaron and his sons. The blood is what is left over from a bull and two rams which had been slaughtered earlier. The rest of the meat of the ordination ram is eaten by Aaron and his sons. Thus although there are some similarities between these two rituals, the differences are probably much greater. In the light of 4) above one could say that there might be an element of "riddance" in this ritual, at least in the way in which the Corinthians practise it. The new ordinates are cleansed of elements which might be considered a threat to their future ministry.

- The ritual of the red heifer in Numbers 19 is also different from the ritual described in Mlazi, where a heifer is used. In Numbers the blood is burned and the ashes kept, whereas in Mlazi both are kept.

- One similarity is that in both cases the ashes are kept for future rituals. Something similar also happens at Phepheni.

- Another similarity between Numbers 19 and the rituals at Mlazi and Phepheni is that the whole animal is burned, which makes it not only similar to the red heifer, but to a hațtā't in general.

- In this regard the function of cleansing could be further explored, since it does not sound as if it is all that different from purification in Priestly texts.

It should thus be clear that some of the rituals described in $\mathrm{P}$ texts are practised by the Corinthians and this probably happens by means of a process of inculturation. There is a some irony in this. Apart from being highly ritualised, priestly texts are also known for the clear boundaries they demarcate between Israel and the nations. ${ }^{61}$ The tendency to exclude is another crucial part of the Priestly worldview. In Priestly texts rituals are usually not performed for the sake of inclusion, but rather for exclusion. Yet it is exactly these texts that are (re)enacted in the rituals of the Corinthians.

\section{Conclusion}

In this article we specifically focused on rituals in the CCSA as well as in Priestly texts. We have focused on the role of a certain repertoire of rituals in the CCSA in social capital formation in a South African context and it seems that the purpose of this repertoire of liturgical rituals is first and foremost cleansing aimed at inclusion. Social capital formation is a central concept in social development theory and has even been called the missing link in social development. However, to come to a conclusion in which the rituals of the CCSA pertaining to blood and sacrifice can be appreciated as contributing to social capital formation, specifically bonding and bridging capital, it was necessary to revisit the concept of

\footnotetext{
${ }^{61}$ See Esias E. Meyer, "Respect for Animal Life in the Book of Leviticus. How Green Were the Priestly Authors?" OTE 24/1 (2011), 142-158. Or see Nihan, Priestly Torah, 339.
} 
liturgical inculturation as well as the most recent literature pertaining to $\mathrm{P}$. This does not imply that these rituals of the CCSA or bonding capital as such are viewed only and exclusively in a positive light by the authors; however, what we do want to emphasise is the fact that these rituals should not from the outset only be viewed in a negative way, not allowing any space for a positive appreciation of some aspects. As such, this article is of course only one small piece in the much larger puzzle and does not attempt to provide a comprehensive answer to all the questions pertaining to ritual in either the CCSA or $\mathrm{P}$, but in this way we have hopefully contributed one small but helpful perspective, namely that seemingly strange ritual practices such as the ones described in this article can serve an important function as part of the glue that holds a community together. 